\title{
Surface Properties and MC3T3-E1 Cell Response of Cortical Bone Allografts Modified with Low-Concentration Phosphoric Acid
}

\author{
Zengfa Huang ${ }^{\mathrm{a}}$ Cheng Cheng ${ }^{\mathrm{a}}$ Jing Wang ${ }^{\mathrm{a}}$ Hui Wei $^{\mathrm{a}}$ Xianzhe Liu ${ }^{\mathrm{a}}$ Xinxin Yan ${ }^{\mathrm{a}}$ \\ Yan Zhou ${ }^{b}$ Yunlu Liu ${ }^{a}$ Shuhua Yang ${ }^{\text {a }}$ \\ ${ }^{a}$ Department of orthopedics, Union Hospital, Tongji Medical College, Huazhong University of Science \\ and Technology, Wuhan, ${ }^{b}$ Department of orthopedics, Suining Municipal Hospital of Traditional \\ Chinese Medicine, Suining, Sichuan Province, China
}

\section{Key Words}

Low-concentration phosphoric acid • Cortical allograft • Surface structure $\bullet$ Large segmental bone defect • Osteopontin.

\begin{abstract}
Background/Aims: This experimental study aimed to evaluate the effect of low-concentration phosphoric acid on the surface structure of cortical allografts. Methods: Allogenic cortical bones were obtained from femurs and tibias of New Zealand white rabbits. The bones were modified by treatment with various concentrations of phosphoric acid (10\%, $20 \%$ or $30 \%)$ for 10,30 or 60 minutes, then evaluated by the following methods: 3-(4,5-Dimethyl-2-thiazolyl)-2,5diphenyl-2H-tetrazolium bromide (MTT) and LIVE/DEAD assay, alkaline phosphatase (ALP) assay, biomechanical properties testing, contact angle detection, quantitative real-time polymerase chain reaction (Q-PCR), western blotting and scanning electron microscopy (SEM). Results: Compared with the other groups, the group modified with $10 \% \mathrm{H}_{3} \mathrm{PO}_{4}$ for 10 minutes had lower cytotoxicity according to MTT and LIVE/DEAD assays, higher hydrophilicity in the contact angle detection test and greater stability in the biomechanical properties test. Moreover, an up-regulation of osteopontin (OPN) in bones modified with $10 \% \mathrm{H}_{3} \mathrm{PO}_{4}$ was observed by Q-PCR and western blotting. In addition, ALP assay and SEM showed that surface porosity and osteoinductivity were increased in the group modified with $10 \% \mathrm{H}_{3} \mathrm{PO}_{4}$. Conclusions: Low-concentration phosphoric acid may be a potential method for surface modification of cortical allografts. Further animal experiments and animal infection model studies are required to validate the efficacy of surface-modified cortical allografts to repair large segmental bone defects.

Z. Huang and C. Cheng contributed equally to this work.

Shuhua Yang and Jing Wang

KARGER
Department of orthopedics, Union Hospital, Tongji Medical College, Huazhong University of Science and Technology No.1277 Jiefang Avenue, Jianghan District, Wuhan, 430022 (China); E-Mail yangshuhuayw2014@163.com/wangjingwj0987@163.com 


\section{Introduction}

A large segmental bone defect (LSBD) caused by trauma, infection, congenital bone disease or tumor resection is always difficult to treat, as multiple surgical procedures are usually required to recreate an effective union and restore the bone's basic function [1]. Currently, cortical allograft transplantation is the most widely-used treatment for LSBD. According to current data, more than 500,000 bone-grafting procedures are performed in America every year [2-4]. Transplant rejection and other diseases have been reduced through strict control of the establishment of bone banks and bone resources. Nevertheless, studies have reported that the five-year success rate after allograft bone transplantation is only $20 \%$ due to complications such as nonunion, fracture and infections [5]. The slowness of host bone creeping substitution and angiogenesis caused by the lack of biological activity and osteoinductivity is considered the main reason for this low success rate $[6,7]$.

Many studies have reported that the surface morphology of bone material implants had important effects on the adhesion, proliferation and differentiation of bone cells, and the effects are reflected in the osteogenic process and the response to various growth factors $[8,9]$. The surface structure of the modified materials (toughness $R_{a}>0.5 \mu \mathrm{m}$ ) can stimulate osteoinductivity, promote bone cell adhesion and proliferation, regulate the release and enrichment of bone morphogenetic protein-2/transforming growth factor- $\beta$ (BMP-2/ TGF- $\beta$ ) [10], induce bone marrow stem cells to differentiate into osteoblasts [11], and reduce osteoclast activity [12]. Types of implant materials with surface osteoinductivity have been developed quickly. Some researchers have suggested that sandblasting and femtosecond laser technology can be used to prepare surface-modified titanium with osteoinductivity $[13,14]$. Our unpublished study also revealed that an acid-treated titanium surface may increase bone union.

Reports have suggested that cancellous bone graft materials with $R_{a}$ of $0.5-1.5 \mu \mathrm{m}$ by morphological observation performed perfectly in bone graft treatment and that their surface morphology was considered as the most suitable for osteoinductivity [15]. Our follow-up study of a porous tantalum rod in the early and intermediate stages of necrosis of the femoral head has suggested that a biomimetic trabecular bone surface can be combined closely with bone tissue [16]. Cortical allograft surfaces are smooth and dense, with a surface roughness of $0.09 \mu \mathrm{m}$ [15]. This surface may not provide an appropriate biological interface for the adhesion and proliferation of bone cells in the absence of cytokines, and we suspect that this may be another major factor responsible for the slowness of host bone creeping substitution. Conventional methods of re-structuring surfaces such as plasma spraying and anodic oxidation require high temperatures, and/or strongly acidic, alkaline or electrochemical conditions. However, these methods are inappropriate for the modification of cortical bone because of its mild physico-chemical properties. In this study, we used different concentrations of $\mathrm{H}_{3} \mathrm{PO}_{4}$ to modify allogenic cortical bone and tested whether the surface could be structured in a way which would stimulate osteoinductivity. As a result, we hoped to develop a safer and more efficient method that has less influence on the physicochemical properties of allogenic cortical bone. The method was required to stimulate the osteoinductivity of allogenic cortical bone and provide a suitable biological interface for host bone creeping substitution.

We hoped to develop a suitable surface structure modification method that could improve surface bone biocompatibility, activate osteoinductivity and accelerate the bone growth and creeping substitution rate in allogenic cortical bones. We also aimed to evaluate these functions and clarify the mechanism of the "bone bed" for the treatment of LSBD.

\section{Materials and Methods}

This study was approved by the Institutional Animal Care and Use Committee of Tongji Medical College, Huazhong University of Science and Technology. 


\section{Cellular Physiology Cell Physiol Biochem 2017;41:1572-1583 \\ \begin{tabular}{ll|l} 
and Biochemistry Published onIIne: IVarch 27, 2017 & $\begin{array}{l}\text { (c) 2017 The Author(s). Published by S. Karger AG, Basel } \\
\text { www.karger.com/cpb }\end{array}$
\end{tabular}}

Huang et al.: Phosphoric Acid Modifiy Cortical Allografts

Materials and cell culture

Allogenic cortical bone: Fresh bone tissues were derived from femurs and tibias of New Zealand white rabbits (female, 3-5 kg, provided by the Laboratory Animal Center of Huazhong University of Science and Technology). The rabbits were sacrificed by an overdose of $3 \%$ sodium pentobarbital (provided by Union Hospital, Wuhan, Hubei Province, China). After soft tissues and cancellous bone were removed, samples of cortical bone 5-10 $\mathrm{mm}$ in diameter and 3-5 mm thick were prepared from the femoral and tibial cortical bones. Samples were stored at $-80^{\circ} \mathrm{C}$. Cortical bone samples were prepared as follows: (1) mechanical cleaning (double distilled water and PBS for five minutes, three times), (2) ultrasonic cleaning (40 minutes, three times), (3) chemical cleaning (non-ionic detergents, hydrogen peroxide and alcohol for five minutes, three times each), (4) high-pressure steam sterilization, (5) storage of samples at $-80^{\circ} \mathrm{C}$.

\section{Fabrication of materials}

The cortical bones were sterilized by UV light for 30 minutes in a laminar flow hood, and then placed into 12-well plates for surface modification. The intervention liquids were $10 \% \mathrm{H}_{3} \mathrm{PO}_{4}, 20 \% \mathrm{H}_{3} \mathrm{PO}_{4}$ and $30 \% \mathrm{H}_{3} \mathrm{PO}_{4}$, and the intervention times were 10 minutes, 30 minutes and 60 minutes. After treatment, the modified cortical bones were washed three times (10 minutes per time) with sterile distilled water to remove the residual solution from the material surface.

\section{Biocompatibility}

MTT and LIVE/DEAD assay. Effects of the modified allogenic cortical bones on the viability of MC3T3-E1 cells were analyzed by MTT assay. Modified and unmodified cortical bones were soaked in $\alpha$-MEM (Gibco BRL, Grand Island, NY, USA) supplemented with 10\% FBS (Invitrogen, Carlsbad, CA, USA) and 1\% penicillinstreptomycin for $24 \mathrm{~h}$, then the medium was removed and designated 'leach liquor'. The modified cortical bone samples were placed into 12-well plates and MC3T3-E1 cells were seeded onto the bone samples at a density of 20,000 cells/well. As a control, MC3T3-E1 cells were cultured in $\alpha$-MEM supplemented with 10\% FBS and 1\% penicillin-streptomycin. In the modified and un-modified groups, MC3T3-E1 cells were cultured in the appropriate leach liquor. MC3T3-E1 cells in all groups were cultured in an incubator with $5 \% \mathrm{CO}_{2}$ at $37^{\circ} \mathrm{C}$ for $48 \mathrm{~h}$. Then, cells were collected, seeded into 96-well plates at a density of 3,000 cells/ well and incubated for $24 \mathrm{~h}$. Cell growth was measured by MTT (Nanjing Jiancheng Bioengineering Institute, Nanjing, China) assay. A $10-\mu \mathrm{L}$ aliquot of MTT solution $(5 \mathrm{mg} / \mathrm{mL})$ was added into each well, and incubated for an additional $4 \mathrm{~h}$. After incubation, medium containing MTT was removed, $150 \mu \mathrm{L}$ of DMSO (Nanjing Jiancheng Bioengineering Institute) was added to each well to dissolve the resulting formazan crystals, and plates were oscillated for 15 minutes. The absorbance of each well was determined by microplate reader at a wavelength of $540 \mathrm{~nm}$.

A ReadyProbes ${ }^{\circledR}$ Cell Viability Imaging Kit (Life Technologies, Gaithersburg, MD, USA) was used to detect cell viability after $24 \mathrm{~h}$ of incubation, in which living cells are stained by a blue dye and a green dye is used to stain the dead cells. Stained cells were analyzed under a fluorescence microscope (DP72, Olympus, Shinjuku, Tokyo, Japan)

Alkaline phosphatase (ALP) assay. MC3T3-E1 cells were seeded onto the modified allogenic cortical bone samples in 24-well plates at a density of 10,000 cells/well to measure ALP activity. The medium was changed every two days. After 3, 7 and 14 days of culture, cells that grew and proliferated on the cortical bone samples were collected, washed twice with PBS and immersed in lysis buffer at $4^{\circ} \mathrm{C}$ for 30 minutes. ALP activity was assayed by microplate reader using an ALP kit (Nanjing Jiancheng Bioengineering Institute) at a wavelength of $490 \mathrm{~nm}$, according to the manufacturer's instructions.

Biomechanical properties test

Allogenic cortical bone samples were thawed at room temperature before mechanical testing. After modification, the bone samples were subjected to three-point bending and kept moist with an isotonic saline solution during the tests. Briefly, samples of modified bone were placed in an MTS testing machine (1$\mathrm{mm}$ diameter discharge head, $2.0 \mathrm{~mm} / \mathrm{min}$ loading speed, $15-\mathrm{mm}$ span) to record load and deflection values at each time point. Then, load-deflection curves were determined, maximum load and stiffness values were obtained. 


\section{Cellular Physiology Cell Physiol Biochem 2017;41:1572-1583

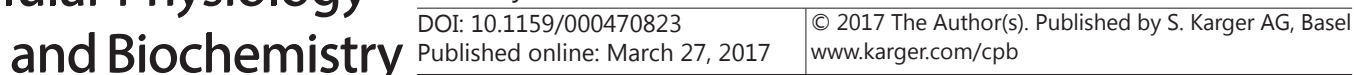

Huang et al.: Phosphoric Acid Modifiy Cortical Allografts

Contact angle detection

The modified allografts were dried overnight at room temperature and then used for contact angle measurement with distilled water. Six samples were measured in every group, and three different areas on each sample were measured with a static droplet measuring instrument (JC2000C1; Zhongcheng, Shanghai) at room temperature. A $2 \mu \mathrm{L}$ drop of distilled water was carefully loaded onto the surface of the allograft samples and left for $20 \mathrm{~s}$ before measurement. The contact angle of the substrate was analyzed using the software supplied by the manufacturer.

\section{Q-PCR and western blotting}

Samples of modified cortical bone were placed into 12-well plates. MC3T3-E1 cells were seeded into the wells at a density of 20,000 cells/well and cultured in osteogenic induction medium ( $\alpha$-MEM supplemented with 10\% FBS, $100 \mathrm{mM}$ dexamethasone, $10 \mathrm{mM} \beta$-glycerophosphate, and $50 \mu \mathrm{g} / \mathrm{mL}$ ascorbic acid) for 14 days. Then, total RNA from each experimental group was extracted using Trizol reagent (Invitrogen, Carlsbad, CA, USA) according to the manufacturer's protocol. Quantitative real-time PCR (Q-PCR) reactions were carried out and monitored with an ABI PRISM 7500 Real-Time PCR System (Applied Biosystems, Foster City, CA, USA). Expression levels of the target genes (bone morphogenetic protein 2 (BMP2), runtrelated transcription factor 2 (Runx2) and osteopontin (OPN)) were normalized to the reference gene glyceraldehyde dehydrogenase (GAPDH). All PCRs were performed in triplicate and the primers used were as follows:

GAPDH, 5' - ACCACAGTCCATGCCATCAC-3' (forward),

5' - TCCACCCTGTTGCTGTA-3' (reverse);

BMP2, 5'-AACGAGAAAAGCGTCAAGCC-3' (forward),

5'-AGGTGCCACGATCCAGTCAT-3' (reverse);

Runx2, 5'-AGCGGACGAGGCAAGAGTTT-3' (forward),

5'-AGGCGGGACACCTACTCTCATA-3' (reverse);

OPN, 5'-AGGAGTTTCCAGGTTTCTGATGA-3' (forward),

5'-CTGCCCTTTCCGTTGTTGTC-3' (reverse).

Samples of modified cortical bone were placed into 12-well plates. MC3T3-E1 cells were seeded into the wells at a density of 20,000 cells/well and cultured in osteogenic induction medium as described above for 14 days. Then, MC3T3-E1 cells were lysed in lysis buffer on ice for 30 minutes. For western blot analysis, $300 \mu \mathrm{g}$ of total protein was resolved by $10 \%$ SDS-PAGE, and proteins were transferred onto a polyvinylidene difluoride (PVDF) membrane. Anti-BMP2 (1:1,000), anti-Runx2 (1:10,000), anti-OPN (1:10,000) and antiGAPDH $(1: 10,000)$ antibodies (all from Abcam, Cambridge, MA, USA) were used for immuno-blotting. GAPDH was used as the loading control. The horseradish peroxidase-conjugated secondary antibody was used at a 1:10,000 dilution. Images were analyzed by Quantity One 4.62 software (BioRad, Hercules, CA. USA).

Scanning electron microscopy (SEM)

Modified cortical bone samples were placed into 12-well plates and MC3T3-E1 cells were seeded into the wells at a density of 20,000 cells/well, and cultured in $\alpha$-MEM for 3 days. Then, the cortical bones were washed three times with PBS, fixed with $2.5 \%$ glutaraldehyde for $12 \mathrm{~h}$, dehydrated by critical-point drying and gold coated under vacuum. Cell surface morphology, surface material adhesion, and the threedimensional pore structure of the material were observed using SEM, and the pore size of the material's surface was analyzed.

Statistical analysis

Data are expressed as mean \pm SD. SPSS 17.0 statistical software was used for statistical analysis. ANOVA with Dunnett's test was used to assess differences between control and experimental groups; a $P$ value $<$ 0.05 was considered statistically significant. Each experiment was performed independently, three times. 


\section{Results}

Hydrophilicity of the modified cortical bone was determined by water contact angle measurements, and the results were shown in Table 1. The value decreased according to the duration of treatment and the concentration of $\mathrm{H}_{3} \mathrm{PO}_{4}$. A significant difference was only found between the group modified by $30 \% \mathrm{H}_{3} \mathrm{PO}_{4}$ for 60 minutes and the un-modified group ( $\mathrm{Nb}$ group).

Surface toxicity of cortical bone was evaluated by MTT and LIVE/DEAD assays (Fig. 1). MTT showed that MC3T3-E1 cell growth was significantly inhibited by $20 \%$ and $30 \%$ $\mathrm{H}_{3} \mathrm{PO}_{4}(P<0.05)$. However, there was no significant difference between the groups modified with $10 \% \mathrm{H}_{3} \mathrm{PO}_{4}$ and the normal culture group (Nc group) $(P>0.05)$ (Fig. $\left.1 \mathrm{~A}\right)$. Cell viability staining showed more dead cells in the $30 \% \mathrm{H}_{3} \mathrm{PO}_{4}$ groups, while fewer were apparent in the $10 \% \mathrm{H}_{3} \mathrm{PO}_{4}$ groups (Fig. 1B, 1C).

Table 1. Contact angle of the cortical bone samples following different modifications. CAW $=$ contact angle of water. ${ }^{*} P<0.05$ vs. $\mathrm{Nb}$ (un-modified) group

\begin{tabular}{lccc}
\hline modified condition & \multicolumn{3}{c}{ CAW $\left({ }^{\circ}\right)$} \\
\hline contact time (min) & 10 & 30 & 60 \\
$\mathrm{Nb}$ & $87.8 \pm 9.1$ & - & -- \\
$10 \% \mathrm{H}_{3} \mathrm{PO}_{4}$ & $86.1 \pm 8.6$ & $85.6 \pm 5.8$ & $84.3 \pm 8.9$ \\
$20 \% \mathrm{H}_{3} \mathrm{PO}_{4}$ & $86.0 \pm 7.4$ & $85.0 \pm 4.5$ & $85.5 \pm 7.3$ \\
$30 \% \mathrm{H}_{3} \mathrm{PO}_{4}$ & $84.9 \pm 7.2$ & $83.6 \pm 5.5$ & $82.2 \pm 4.6^{*}$ \\
\hline
\end{tabular}

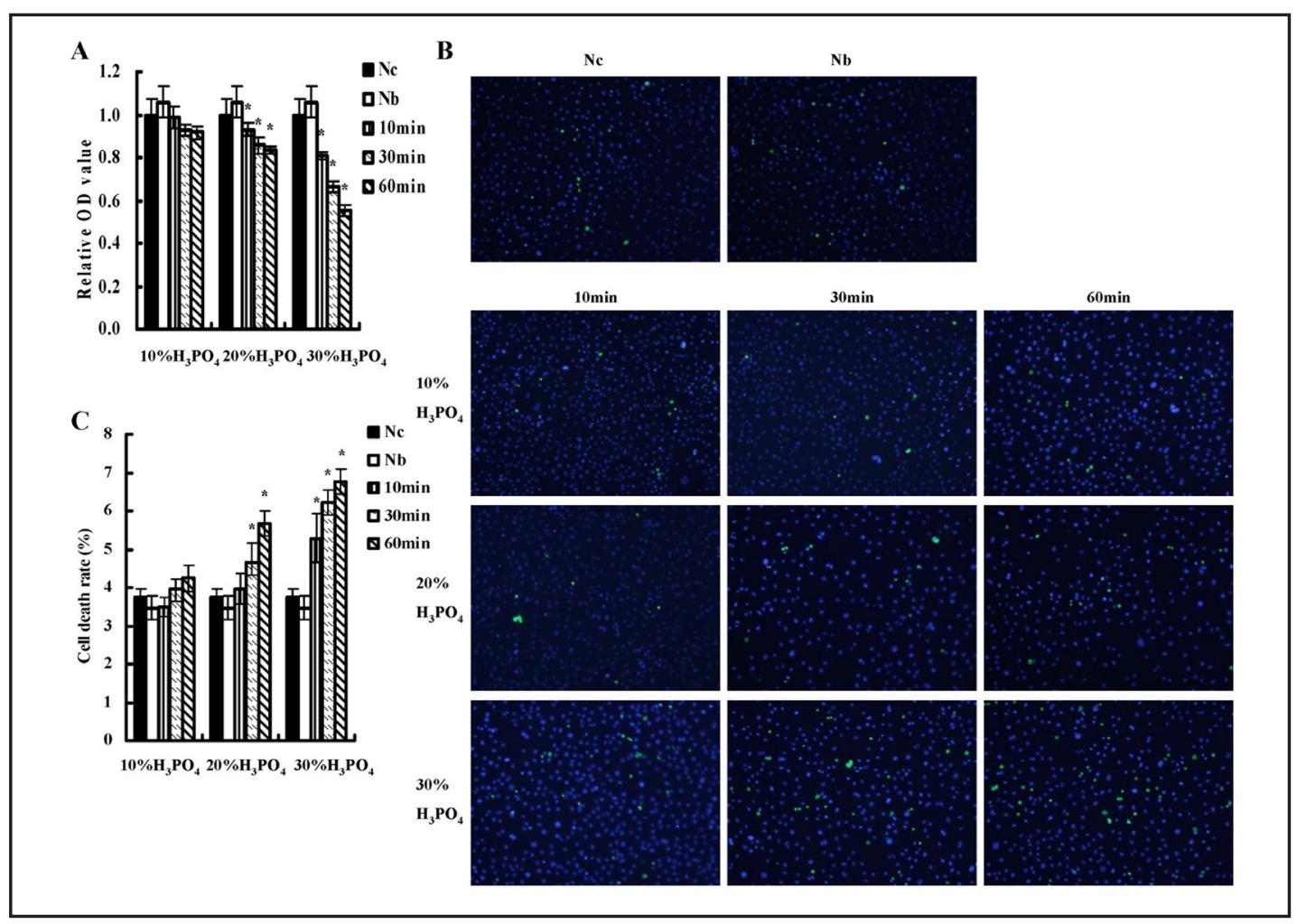

Fig. 1. Results of surface toxicity testing by MTT (A) and LIVE/DEAD assays (B 100× C). Nc group = normal culture group (cells not cultured on the surface of cortical bone) $\mathrm{Nb}=$ un-modified group (cells cultured on cortical bone without modification) $* P<0.05$ vs. Nc group. 


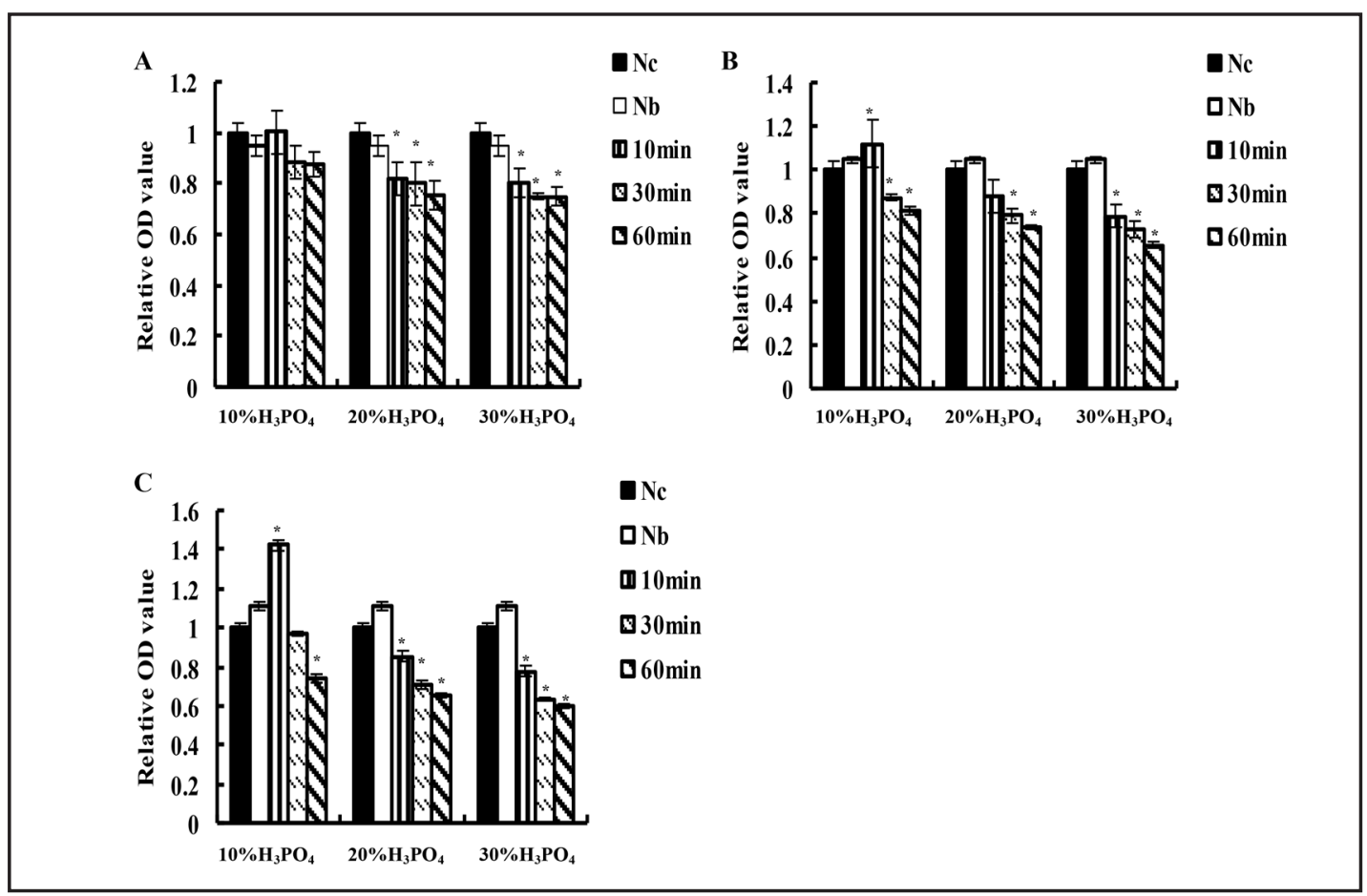

Fig. 2. ALP activity was measured on days 3 (A), 7 (B) and 14 (C) of culture. Data were presented as mean \pm SD of three separate experiments. Nc = normal culture group (cells not cultured on the surface of cortical bone), $\mathrm{Nb}=$ un-modified group (cells cultured on cortical bone without modification). ${ }^{*} P<0.05$ vs. Nc group.

Table 2. Biomechanical test data of the cortical bone samples following different modifications. Results of biomechanical testing of $\mathrm{Nb}$ (un-modified) group, and groups modified with $10 \% \mathrm{H}_{3} \mathrm{PO}_{4}, 20 \% \mathrm{H}_{3} \mathrm{PO}_{4}$ and $30 \% \mathrm{H}_{3} \mathrm{PO}_{4}$. The treatment times were 10,30 and 60 minutes. $* P<0.05$ vs. Nb group

\begin{tabular}{lccccccccc}
\hline Group & & $\mathrm{N}$ & $\begin{array}{c}\text { Mass } \\
(\mathrm{g})\end{array}$ & $\begin{array}{c}\text { Volume } \\
(\mathrm{ml})\end{array}$ & $\begin{array}{c}\text { Length } \\
(\mathrm{mm})\end{array}$ & $\begin{array}{c}\text { Thickness } \\
(\mathrm{mm})\end{array}$ & $\begin{array}{c}\text { Max-Load } \\
(\mathrm{N})\end{array}$ & $\begin{array}{c}\text { Max-Stress } \\
\left(\mathrm{N} / \mathrm{mm}^{2}\right)\end{array}$ & $\begin{array}{c}\text { Elastic } \\
(\mathrm{Mpa})\end{array}$ \\
\hline $\mathrm{Nb}$ & & 6 & $2.65 \pm 0.35$ & $1.76 \pm 0.24$ & $26.25 \pm 3.18$ & $4.9 \pm 0.9$ & $116 \pm 8$ & $104 \pm 8$ & $3064 \pm 128$ \\
$10 \%$ & $10 \mathrm{~min}$ & 6 & $3.08 \pm 0.25$ & $2.06 \pm 0.17$ & $24.08 \pm 2.55$ & $6.1 \pm 0.7$ & $113 \pm 7$ & $98 \pm 9$ & $2996 \pm 101$ \\
$\mathrm{H}_{3} \mathrm{PO}_{4}$ & $30 \mathrm{~min}$ & 6 & $2.9 \pm 0.49$ & $1.93 \pm 0.33$ & $23.48 \pm 2.18$ & $6 \pm 1.4$ & $106 \pm 6$ & $92 \pm 8$ & $2981 \pm 221$ \\
& $60 \mathrm{~min}$ & 6 & $2.92 \pm 0.32$ & $1.95 \pm 0.22$ & $25.17 \pm 2.74$ & $5.6 \pm 0.7$ & $101 \pm 8$ & $88 \pm 7$ & $2916 \pm 93$ \\
& $10 \mathrm{~min}$ & 6 & $2.76 \pm 0.22$ & $1.84 \pm 0.15$ & $23.87 \pm 2.74$ & $5.5 \pm 0.4$ & $120 \pm 37$ & $108 \pm 38$ & $2933 \pm 88$ \\
$20 \%$ & $30 \mathrm{~min}$ & 6 & $3.03 \pm 0.25$ & $2.02 \pm 0.17$ & $25.07 \pm 2.98$ & $5.8 \pm 0.8$ & $106 \pm 11$ & $87 \pm 7$ & $2896 \pm 104$ \\
$\mathrm{H}_{3} \mathrm{PO}_{4}$ & $50 \mathrm{~min}$ & 6 & $2.87 \pm 0.35$ & $1.92 \pm 0.23$ & $24.85 \pm 2.46$ & $5.6 \pm 0.9$ & $97 \pm 8$ & $87 \pm 9$ & $2868 \pm 110^{*}$ \\
& $10 \mathrm{~min}$ & 6 & $2.82 \pm 0.17$ & $1.88 \pm 0.11$ & $24.67 \pm 3.23$ & $5.5 \pm 0.8$ & $100 \pm 6$ & $91 \pm 6$ & $2893 \pm 122$ \\
$30 \%$ & $30 \mathrm{~min}$ & 6 & $3.02 \pm 0.34$ & $2.01 \pm 0.22$ & $24.73 \pm 2.64$ & $5.8 \pm 0.7$ & $98 \pm 6$ & $88 \pm 9$ & $2840 \pm 132^{*}$ \\
$\mathrm{H}_{3} \mathrm{PO}_{4}$ & $30 \mathrm{~min}$ & 6 & $2.88 \pm 0.29$ & $1.92 \pm 0.19$ & $23.97 \pm 2.2$ & $5.7 \pm 0.6$ & $93 \pm 8^{*}$ & $83 \pm 7^{*}$ & $2783 \pm 125^{*}$ \\
\hline
\end{tabular}

The ALP activity of the different experimental groups was measured on days 3, 7 and 14 (Fig. 2). ALP activity decreased in the treated groups at all three concentrations of $\mathrm{H}_{3} \mathrm{PO}_{4}$ as well as in the un-modified group at day 3 (Fig. 2A). The group modified with $10 \% \mathrm{H}_{3} \mathrm{PO}_{4}$ for 10 minutes had higher ALP activity than the Nc group $(P<0.05)$ (Fig. 2B) on day 7 and the increase was also found on day 14 (Fig. 2C). Other groups modified with phosphoric acid showed lower ALP activity than the Nc group at day 7 and 14 (Fig. 2B, C). 


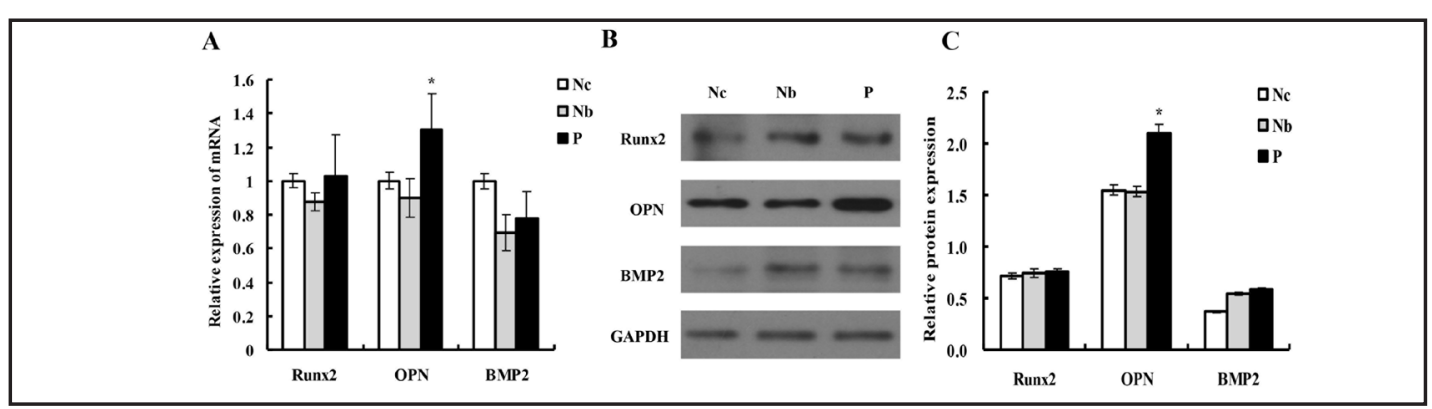

Fig. 3. mRNA expression of BMP2, Runx2 and OPN in MC3T3-E1 cells analyzed by Q-PCR (A) and western blotting $(\mathrm{B}, \mathrm{C}) . \mathrm{Nc}=$ normal culture group (cells not cultured on the surface of cortical bone) $\mathrm{Nb}=$ un-modified group (cells cultured on cortical bone without modification). $P=10 \% \mathrm{H}_{3} \mathrm{PO}_{4}$ modified group. ${ }^{*} P<0.05$ vs. Nc group.

Table 3. Pore size and surface porosity of the cortical bone samples following different modifications. $* P<0.05$ vs. $\mathrm{Nb}$ (un-modified) group

\begin{tabular}{lcc}
\hline Groups & Pore size $(\mu \mathrm{m})$ & Surface porosity $(\%)$ \\
\hline $\mathrm{Nb}$ & $0.55 \pm 0.17$ & $10.0 \pm 2.2$ \\
$10 \% \mathrm{H}_{3} \mathrm{PO}_{4}$ & $1.42 \pm 0.54^{*}$ & $16.8 \pm 1.7^{*}$ \\
$20 \% \mathrm{H}_{3} \mathrm{PO}_{4}$ & $1.18 \pm 0.70^{*}$ & $15.8 \pm 1.6^{*}$ \\
$30 \% \mathrm{H}_{3} \mathrm{PO}_{4}$ & $0.89 \pm 0.45^{*}$ & $17.7 \pm 1.9^{*}$ \\
\hline
\end{tabular}

Maximum load, maximum stress and elasticity values of allogenic cortical bone samples in the $\mathrm{Nb}$ group were higher than those in the groups modified with phosphoric acid (Table 2). Values in the group modified with $30 \% \mathrm{H}_{3} \mathrm{PO}_{4}$ decreased the most, while values in the group modified with $10 \% \mathrm{H}_{3} \mathrm{PO}_{4}$ were similar to the $\mathrm{Nb}$ group.

According to the results of water contact angle testing, MTT assay, ALP assay and biomechanical properties testing, we found that the group modified with $10 \% \mathrm{H}_{3} \mathrm{PO}_{4}$ for 10 minutes showed more beneficial effects than others. Therefore, we chose treatment with $10 \% \mathrm{H}_{3} \mathrm{PO}_{4}$ for 10 minutes for subsequent experiments. We tested the expression of BMP2, Runx2 and OPN in MC3T3-E1 cells after culture with osteogenic induction medium for 14 days. We observed increased expression of OPN protein in the $10 \% \mathrm{H}_{3} \mathrm{PO}_{4}$ group, while no difference was found in the normal culture group and the un-modified group. The results showed that there was no significant difference between the levels of BMP2 and Runx2 proteins in the three groups (Fig. 3).

Surface porosity of the groups modified by $10 \%, 20 \%$, and $30 \% \mathrm{H}_{3} \mathrm{PO}_{4}$ for 10 minutes and the Nb group were measured using MATLAB $囚$ (Mathworks, Natick, MA, USA) and Photoshop (Adobe Systems Inc., San Jose, CA, USA) software. Surface porosity in the 10\%, 20\%, and $30 \% \mathrm{H}_{3} \mathrm{PO}_{4}$ groups was $16.8 \%, 15.8 \%$ and $17.7 \%$ respectively, all of which were higher than the $\mathrm{Nb}$ group (Table 3 ). The surface structure of the cortical bone changed after modification by $\mathrm{H}_{3} \mathrm{PO}_{4}$ for 10 minutes. Pore number and aperture were increased in the $\mathrm{H}_{3} \mathrm{PO}_{4}$ group compared to the Nb group. MC3T3-E1 cells exhibited a flat appearance and were spread out over the surface in $\mathrm{H}_{3} \mathrm{PO}_{4}$ modified groups. Cells extended their pseudopodia on the surface of phosphoric acid-modified cortical bone samples (Fig. 4).

\section{Discussion}

We have recently shown that a biomimetic trabecular bone surface could be combined closely with bone tissue [16], which suggested that modification of the bone surface could be used for regenerative medicine. In this study, we first tested a new method of modifying the cortical bone surface and then assessed the surface toxicity, biomechanical properties, surface adhesion and osteogenic differentiation potential of MC3T3-E1 cells loaded on the modified surface in vitro.

\section{KARGER}




\section{Cellular Physiology and Biochemistry}

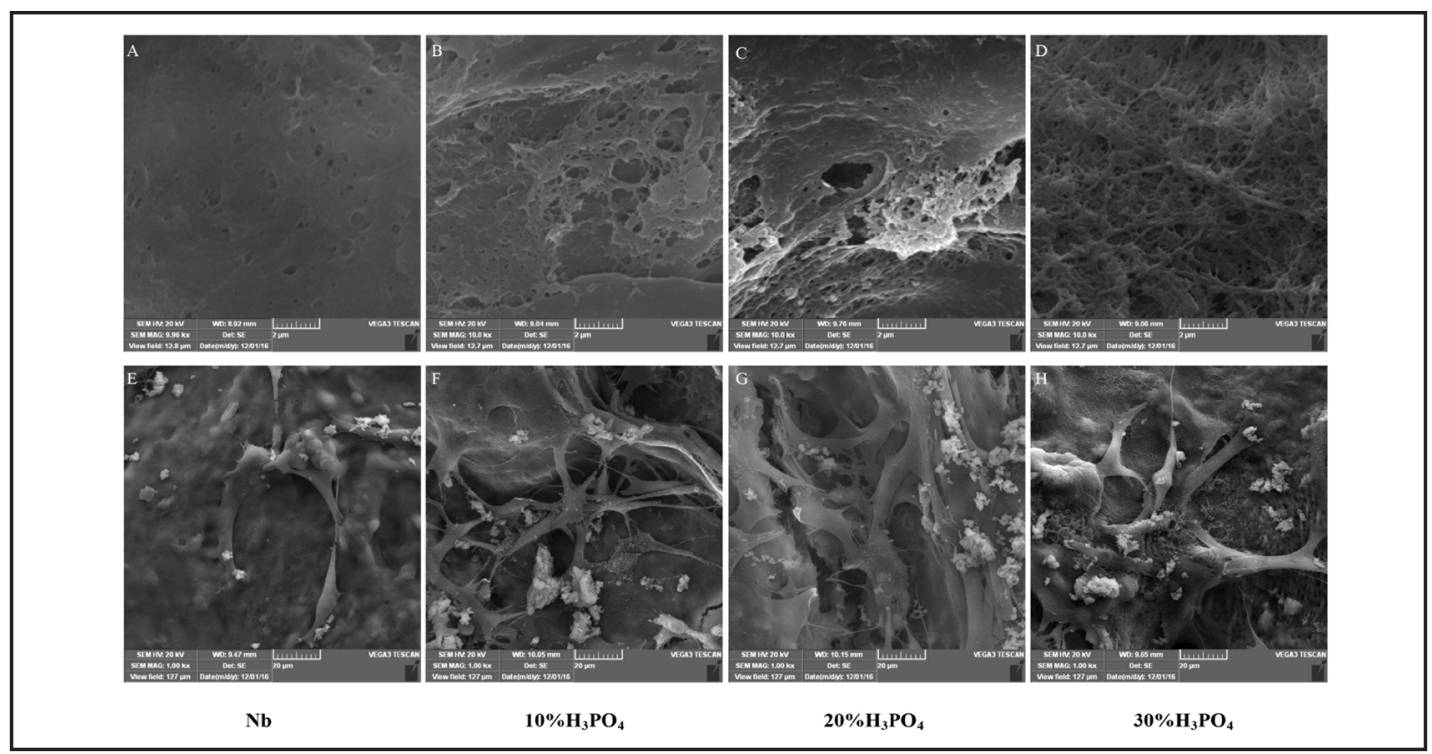

Fig. 4. SEM observations of allograft surface (A-D, 10000x) and MC3T3-E1 morphology after 3 days of culture $(\mathrm{E}-\mathrm{H}, 1000 \times)$.

Allogenic cortical bone has the potential for use as a bone substitute material in autogenous transplantation because of its normal bone strength, large size range and accessibility. Furthermore, these bones are mainly used to repair large bone defects after tumor resection. A prospective study by Gerrand et al. [17] reported the use of allogenic cortical bone with intramedullary bone cement for the repair of bone defects caused by tumor resection. After five years of follow up, Gerrand found that allogenic cortical bone in the body had a survival rate of $86 \%$ and the incidence rate of fracture and nonunion was $9 \%$ and $15 \%$, respectively. In addition, functional evaluation revealed that the outcome of osteochondral allografts was poor, while intercalary allografts produced the best results. Moran et al. [18] also reported seven cases in which a free fibula was inserted into the allogenic bone medullary cavity to repair defects caused by bone tumors in children. These had a limb survival rate of $100 \%$, an average bone healing time of nine months, and no instances of fracture or infection occurred within the 36-month follow-up period.

Most previous LSBD studies started by using various methods to modify the metal and tantalum with the aim of improving biological performance [19]. In order to optimize its biological properties in vivo, many methods have been used to modify the surface characteristics of tantalum metal, including acid pickling with $\mathrm{HF} / \mathrm{HNO}_{3}$ or $\mathrm{HC} 1 / \mathrm{H}_{2} \mathrm{SO}_{4}$ [20], biomimetic coatings [21, 22], the sol-gel method [23-25], anodic oxidation, alkaline-heat treatment, tantalum pentoxide $\left(\mathrm{Ta}_{2} \mathrm{O}_{5}\right)$ nanotube decoration [26], layer-by-layer depositions [24], and surface functionalization [25, 26]. However, to our knowledge, no studies of surface modification of allogenic cortical bone have been reported. In addition, the main problem with the surface modification strategies was the shortage of porous surface structure for osteoblast adhesion and proliferation. Acid modification could form a rough and multiporous surface structure on the implant and increase the contact area of the implanted cortical bone, which may result in the early attachment and growth of bone cells. Mangano et al. reported that micron scale porous structures were formed after acid etching with a pure titanium implant [27]. With high free energy, this surface could combine with implants better, and stimulate the formation of connective and vascular tissues. The acid modification methods generally aimed to alter surface micro-roughness. Among these acids, phosphoric acid was of interest because of its influence on the cell response due to the potential change in physical characteristics of the surface and the influence of the remaining phosphate on the surface on cell behavior [28]. Previous studies have shown that phosphate ions promote 
cell adhesion and osteogenic differentiation of various cell types, for example periodontal ligament cells, osteoblasts and cementoblasts [29-31]. ALP activity is an osteoblast differentiation marker in MC3T3-E1 cells. In the present study, the group modified by $10 \%$ phosphoric acid for 10 minutes produced significantly higher ALP activity and more stable biomechanical properties. We therefore concluded that phosphoric acid solution might be a potential surface modification method.

Our research showed that the surface characteristics of allogenic cortical bone were slightly changed by $\mathrm{H}_{3} \mathrm{PO}_{4}$ when observed by SEM. We found that the surface structure of cortical bone became more rough and porous. When MC3T3-E1 cells were cultured in the modified group they adhered with more "pseudopods" than in the un-modified group. We therefore assumed that bone surface structure might play an important role in the attachment and growth of cells. Previous studies have shown that surface roughness could affect osteoblast differentiation and proliferation [32-34]. One previous study also showed that low-concentration phosphoric acid as well as high concentration phosphoric acid might alter titanium surface morphology [28]. However, although low-concentration phosphoric acid has a slight impact on the biomechanical environment of the cortical bone, its toxicity was manageable, as determined by MTT, LIVE/DEAD assay and biomechanical experiments. It is worth mentioning that this process showed great promise for future animal experiments and clinical studies.

Our results (Fig. 3) showed an up-regulation of OPN mRNA and protein in the $10 \%$ $\mathrm{H}_{3} \mathrm{PO}_{4}$ modified group. However the expression of BMP2 and Runx2 showed no significant difference among the three groups according to the results of Q-PCR and western blotting. We therefore concluded that OPN was acting as a chemoattractant for MC3T3-E1 cells binding to a surface. Wu et al. reported that modification of a surface with calcined hydroxyapatite composites could enhance OPN expression after 6 days in culture $(P<0.05)$ in human fetal osteoblasts (hFOB 1.19) [35]. Wu et al. reported that $\mathrm{PO}_{4}^{3-}$ could stimulate OPN expression in MC3T3-E1 osteoblastic cells [36]. OPN is a secreted glycoprotein with functional and structural characteristics of a matricellular protein. Surfaces coated with OPN promote cell adhesion of MC3T3-E1/C4 osteoblastic cells better than those with no protein [37]. OPN contains several cell adhesive domains and the regulation of bone cell adhesion has been suggested by several observations. OPN is localized to the mineralized collagenous matrix for bone cell adhesive interactions during bone formation and remodeling [38]. In addition, OPN is produced at high levels by developing osteoblasts, and it has been shown to mediate substrate attachment of osteoblasts in vitro [39].

The influence of surface hydrophilicity on cell behaviors remains controversial. It has been observed that cell attachment, adhesion and bone apposition increase on hydrophilic surfaces [40-42]. In contrast, it has also been indicated that decreased surface wettability promotes cell attachment and protein adsorption [43]. In the present study, the surface hydrophilicity was related to the concentration of $\mathrm{H}_{3} \mathrm{PO}_{4}$, but the effect was not significant, though cell attachment and the expression of OPN were marked on surfaces modified with $10 \% \mathrm{H}_{3} \mathrm{PO}_{4}$. Thus, the surface hydrophilicity may not be a main factor regulating cell response in this setting.

There were some limitations to our study. Firstly, our experiment only involved surface materials and lacked animal experiments. Secondly, only rabbit cortical bones were selected and analyzed. Lastly, blood supply in tissues around the cortical bone plays a pivotal role in LSBD healing [44, 45], and bone regeneration improves when blood supply is enhanced [4648]. However, defects in the vascularization process were not analyzed in our experiments.

\section{Conclusions}

In summary, we have shown for the first time that low-concentration phosphoric acid provides a potential method of modifying the allograft cortical bone surface. We observed that the cortical bone surface modified by low-concentration phosphoric acid enhanced 
Huang et al.: Phosphoric Acid Modifiy Cortical Allografts

OPN expression by MC3T3-E1 cells in vitro, and concluded that OPN then promotes the cells' differentiation and adhesion to the modified surface. Future in vitro studies and an experimental animal model are needed to validate the reparative effects on LSBD. As the incidence of LSBD increases, longitudinal prospective studies are required to confirm our findings.

\section{Acknowledgments}

This work was supported by the National Natural Science Foundation of China (Grants: $81201413,81302344,81371973$ and 81401573 ). The funders had no role in study design, data collection and analysis, decision to publish, or preparation of the manuscript.

\section{Disclosure Statement}

The authors declare they have no competing interests.

\section{References}

1 Cheng BH, Chu TM, Chang C, Kang HY, Huang KE: Testosterone delivered with a scaffold is as effective as bone morphologic protein-2 in promoting the repair of critical-size segmental defect of femoral bone in mice. PLoS One 2013;8:e70234.

2 Cheung C: The future of bone healing. Clin Podiatr Med Surg 2005;22:631-641 viii.

- 3 Feng YF, Wang L, Li X, Ma ZS, Zhang Y, Zhang ZY, Lei W: Influence of architecture of beta-tricalcium phosphate scaffolds on biological performance in repairing segmental bone defects. PLoS One 2012;7:e49955.

-4 Greenwald AS, Boden SD, Goldberg VM, Khan Y, Laurencin CT, Rosier RN: Bone-graft substitutes: facts, fictions, and applications. J Bone Joint Surg Am 2001;83-A:98-103.

5 Calori GM, Mazza E, Colombo M, Ripamonti C: The use of bone-graft substitutes in large bone defects: any specific needs? Injury 2011;42:S56-63.

6 Enneking WF, Campanacci DA: Retrieved human allografts : a clinicopathological study. J Bone Joint Surg Am 2001;83-A:971-986.

7 Yazici C, Takahata M, Reynolds DG, Xie C, Samulski RJ, Samulski J, Beecham EJ, Gertzman AA, Spilker M, Zhang X, O'Keefe RJ, Awad HA, Schwarz EM: Self-complementary AAV2.5-BMP2-coated femoral allografts mediated superior bone healing versus live autografts in mice with equivalent biomechanics to unfractured femur. Mol Ther 2011;19:1416-1425.

-8 Barradas AM, Yuan H, van Blitterswijk CA, Habibovic P: Osteoinductive biomaterials: current knowledge of properties, experimental models and biological mechanisms. Eur Cell Mater 2011;21:407-429; discussion 429.

-9 Chai YC, Roberts SJ, Desmet E, Kerckhofs G, van Gastel N, Geris L, Carmeliet G, Schrooten J, Luyten FP: Mechanisms of ectopic bone formation by human osteoprogenitor cells on CaP biomaterial carriers. Biomaterials 2012;33:3127-3142.

10 Jung RE, Lecloux G, Rompen E, Ramel CF, Buser D, Hammerle CH: A feasibility study evaluating an in situ formed synthetic biodegradable membrane for guided bone regeneration in dogs. Clin Oral Implants Res 2009;20:151-161.

-11 Olivares-Navarrete R, Hyzy SL, Hutton DL, Erdman CP, Wieland M, Boyan BD, Schwartz Z: Direct and indirect effects of microstructured titanium substrates on the induction of mesenchymal stem cell differentiation towards the osteoblast lineage. Biomaterials 2010;31:2728-2735.

-12 Lossdorfer S, Schwartz Z, Wang L, Lohmann CH, Turner JD, Wieland M, Cochran DL, Boyan BD: Microrough implant surface topographies increase osteogenesis by reducing osteoclast formation and activity. J Biomed Mater Res A 2004;70:361-369. 


\section{Cellular Physiology Cell Physiol Biochem 2017;41:1572-1583 \begin{tabular}{l|l|l} 
DOI: 10.1159/000470823 & and Biochemistry Published online: March 27, 2017 & $\begin{array}{l}\text { O 2017 The Author(s). Published by S. Karger AG, Basel } \\
\text { www.karger.com/cpb }\end{array}$
\end{tabular}}

13 Huang Y, Chang T, Yang C, Wu M: Mineralized and osteoid tissue from dental pulp stem cells on micro-arc oxidation titanium in vitro. J Huazhong Univ Sci Technolog Med Sci 2012;32:620-625.

14 Li DH, Liu BL, Song YL, Wu JZ: [Improvement of osseointegration of titanium dental implants by a modified sandblasted surface]. Zhonghua Kou Qiang Yi Xue Za Zhi 2003;38:254-256.

15 Hacking SA, Tanzer M, Harvey EJ, Krygier JJ, Bobyn JD: Relative contributions of chemistry and topography to the osseointegration of hydroxyapatite coatings. Clin Orthop Relat Res 2002;24-38.

16 Liu G, Wang J, Yang S, Xu W, Ye S, Xia T: Effect of a porous tantalum rod on early and intermediate stages of necrosis of the femoral head. Biomed Mater 2010;5:065003.

$\checkmark 17$ Gerrand CH, Griffin AM, Davis AM, Gross AE, Bell RS, Wunder JS: Large segment allograft survival is improved with intramedullary cement. J Surg Oncol 2003;84:198-208.

18 Moran SL, Shin AY, Bishop AT: The use of massive bone allograft with intramedullary free fibular flap for limb salvage in a pediatric and adolescent population. Plast Reconstr Surg 2006;118:413-419.

19 Meenaghan MA, Natiella JR, Moresi JL, Flynn HE, Wirth JE, Baier RE: Tissue response to surface-treated tantalum implants: preliminary observations in primates. J Biomed Mater Res 1979;13:631-643.

20 Buser D, Schenk RK, Steinemann S, Fiorellini JP, Fox CH, Stich H: Influence of surface characteristics on bone integration of titanium implants. A histomorphometric study in miniature pigs. J Biomed Mater Res 1991;25:889-902.

-21 Barrere F, van der Valk CM, Meijer G, Dalmeijer RA, de Groot K, Layrolle P: Osteointegration of biomimetic apatite coating applied onto dense and porous metal implants in femurs of goats. J Biomed Mater Res B Appl Biomater 2003;67:655-665.

22 Miyazaki T, Kim HM, Miyaji F, Kokubo T, Kato H, Nakamura T: Bioactive tantalum metal prepared by $\mathrm{NaOH}$ treatment. J Biomed Mater Res 2000;50:35-42.

-23 Arnould C, Koranyi TI, Delhalle J, Mekhalif Z: Fabrication of tantalum oxide/carbon nanotubes thin film composite on titanium substrate. J Colloid Interface Sci 2010;344:390-394.

-24 Arnould C, Volcke C, Lamarque C, Thiry PA, Delhalle J, Mekhalif Z: Titanium modified with layer-by-layer sol-gel tantalum oxide and an organodiphosphonic acid: a coating for hydroxyapatite growth. J Colloid Interface Sci 2009;336:497-503.

25 Maho A, Detriche S, Delhalle J, Mekhalif Z: Sol-gel synthesis of tantalum oxide and phosphonic acidmodified carbon nanotubes composite coatings on titanium surfaces. Mater Sci Eng C Mater Biol Appl 2013;33:2686-2697.

26 Maho A, Linden S, Arnould C, Detriche S, Delhalle J, Mekhalif Z: Tantalum oxide/carbon nanotubes composite coatings on titanium, and their functionalization with organophosphonic molecular films: a high quality scaffold for hydroxyapatite growth. J Colloid Interface Sci 2012;371:150-158.

27 Mangano C, Perrotti V, Iezzi G, Scarano A, Mangano F, Piattelli A: Bone response to modified titanium surface implants in nonhuman primates (Papio ursinus) and humans: histological evaluation. J Oral Implantol 2008;34:17-24.

28 Osathanon T, Sawangmake C, Ruangchainicom N, Wutikornwipak P, Kantukiti P, Nowwarote N, Pavasant P: Surface properties and early murine pre-osteoblastic cell responses of phosphoric acid modified titanium surface. J Oral Biol Craniofac Res 2016;6:2-9.

29 An S, Ling J, Gao Y, Xiao Y: Effects of varied ionic calcium and phosphate on the proliferation, osteogenic differentiation and mineralization of human periodontal ligament cells in vitro. J Periodontal Res 2012;47:374-382.

-30 Beck GR, Jr.: Inorganic phosphate as a signaling molecule in osteoblast differentiation. J Cell Biochem 2003;90:234-243.

31 Foster BL, Nociti FH, Jr., Swanson EC, Matsa-Dunn D, Berry JE, Cupp CJ, Zhang P, Somerman MJ: Regulation of cementoblast gene expression by inorganic phosphate in vitro. Calcif Tissue Int 2006;78:103-112.

32 Martin JY, Schwartz Z, Hummert TW, Schraub DM, Simpson J, Lankford J, Jr., Dean DD, Cochran DL, Boyan BD: Effect of titanium surface roughness on proliferation, differentiation, and protein synthesis of human osteoblast-like cells (MG63). J Biomed Mater Res 1995;29:389-401.

-33 Kieswetter K, Schwartz Z, Hummert TW, Cochran DL, Simpson J, Dean DD, Boyan BD: Surface roughness modulates the local production of growth factors and cytokines by osteoblast-like MG-63 cells. J Biomed Mater Res 1996;32:55-63. 


\section{Cellular Physiology Cell Physiol Biochem 2017;41:1572-1583

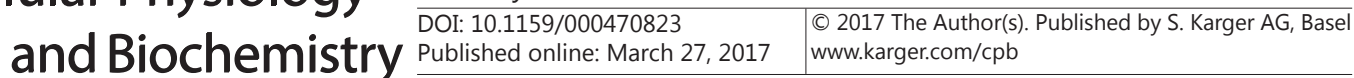

Huang et al.: Phosphoric Acid Modifiy Cortical Allografts

-34 Lovmand J, Justesen J, Foss M, Lauridsen RH, Lovmand M, Modin C, Besenbacher F, Pedersen FS, Duch M: The use of combinatorial topographical libraries for the screening of enhanced osteogenic expression and mineralization. Biomaterials 2009;30:2015-2022.

-35 Wu CC, Huang ST, Lin HC, Tseng TW, Rao QL, Chen MY: Expression of osteopontin and type I collagen of hFOB 1.19 cells on sintered fluoridated hydroxyapatite composite bone graft materials. Implant Dent 2010;19:487-497.

-36 Wu X, Itoh N, Taniguchi T, Nakanishi T, Tanaka K: Requirement of calcium and phosphate ions in expression of sodium-dependent vitamin C transporter 2 and osteopontin in MC3T3-E1 osteoblastic cells. Biochim Biophys Acta 2003;1641:65-70.

-37 Bernards MT, Qin C, Jiang S: MC3T3-E1 cell adhesion to hydroxyapatite with adsorbed bone sialoprotein, bone osteopontin, and bovine serum albumin. Colloids Surf B Biointerfaces 2008;64:236-247.

38 Veis A: Mineral-matrix interactions in bone and dentin. J Bone Miner Res 1993;8:S493-497.

- 39 Puleo DA, Nanci A: Understanding and controlling the bone-implant interface. Biomaterials 1999;20:23112321.

40 Park JW, Kim YJ, Jang JH, Kwon TG, Bae YC, Suh JY: Effects of phosphoric acid treatment of titanium surfaces on surface properties, osteoblast response and removal of torque forces. Acta Biomater 2010;6:1661-1670.

41 Shibata Y, Miyazaki T: Anode glow discharge plasma treatment enhances calcium phosphate adsorption onto titanium plates. J Dent Res 2002;81:841-844.

42 Yamamoto H, Shibata Y, Miyazaki T: Anode glow discharge plasma treatment of titanium plates facilitates adsorption of extracellular matrix proteins to the plates. J Dent Res 2005;84:668-671.

43 Bumgardner JD, Wiser R, Elder SH, Jouett R, Yang Y, Ong JL: Contact angle, protein adsorption and osteoblast precursor cell attachment to chitosan coatings bonded to titanium. J Biomater Sci Polym Ed 2003;14:1401-1409.

-44 Glowacki J: Angiogenesis in fracture repair. Clin Orthop Relat Res 1998;S82-89.

-45 Hankenson KD, Dishowitz M, Gray C, Schenker M: Angiogenesis in bone regeneration. Injury 2011;42:556561.

-46 Street J, Bao M, deGuzman L, Bunting S, Peale FV, Jr., Ferrara N, Steinmetz H, Hoeffel J, Cleland JL, Daugherty A, van Bruggen N, Redmond HP, Carano RA, Filvaroff EH: Vascular endothelial growth factor stimulates bone repair by promoting angiogenesis and bone turnover. Proc Natl Acad Sci U S A 2002;99:9656-9661.

47 Takayama T, Taguchi T, Koyama H, Sakari M, Kamimura W, Takato T, Miyata T, Nagawa H: The growth of a vascular network inside a collagen-citric acid derivative hydrogel in rats. Biomaterials 2009;30:3580-3587.

-48 Wang L, Fan H, Zhang ZY, Lou AJ, Pei GX, Jiang S, Mu TW, Qin JJ, Chen SY, Jin D: Osteogenesis and angiogenesis of tissue-engineered bone constructed by prevascularized beta-tricalcium phosphate scaffold and mesenchymal stem cells. Biomaterials 2010;31:9452-9461. 